\title{
Current Research at IIASA on Environmental Conservation
}

The emphasis at the International Institute for Applied Systems Analysis-IIASA - is on developing a wide range of approaches, procedures, and methods, to deal with the current and emerging problems arising as mankind, technology, and Nature, intersect and interact. The tools of modern science are used for a dual purpose: to understand better such evolving situations, and to evaluate alternative policy-options and management strategies that enable us to adapt to, and benefit from, ever-changing circumstances.

A part of the research at IIASA is focused on issues in agriculture, economics, energy, the environment, and population. It is buttressed by work on new mathematical, conceptual, and modelling, approaches. The interactions of people and their activities with the rest of The Biosphere are an integral component of all these issues.

For instance, IIASA is investigating the impacts on food production of short-term climatic variations and the likely long-term effects of carbon dioxide-induced climatic changes as part of UNEP's World Climate Programme. The study seeks to clarify what changes in the level or frequency of occurrence of climate variables cause a major impact on the viability of an economic and social system. Case-studies of cold, dry, and highaltitude, marginal areas with differing farm and trade arrangements are under way to help appraise which social responses are appropriately resilient.

Our acid rain study is assessing control strategies and energy options. The transformation, transport in the atmosphere, and disposition, of emissions of sulphur dioxide and nitrogen oxides are being examined, as are the effects of concentrations of pollutants on ecosystems. A system of models is being designed for use on a national or international level. These will trace and forecast the environmental and socio-economic consequences of different energy developments in Europe as a policy-guide for the management and control of acidification.

The refinement of concepts, methods, and computerized procedures, for environmental and resource- policy design that stresses adaptive management, grows from the ecological work undertaken by myself and colleagues at IIASA in the early 1970s and reported in this Journal in the Autumn issue of $1976^{*}$. Current research interest focuses on: specific case-studies of fisheries management; the proposed large-scale, unprecedented, interregional transfers of water in the USSR; and problems of resolving conflicts over competing uses of resources.

IIASA has an advantage in studying complex problems related to resource use. As a non-governmental Institute it is able to bring together policy-makers and scholars from many cultures, socio-economic systems, and disciplines in the physical and social sciences. This approach permits analysis of an issue from diverse perspectives and avoids the trap of assuming only a single concept, method, pattern of behaviour, or solution. Our research, now entering its second decade, concerns the interactions between dynamic and constantly-changing systems.

Mankind has always lived with uncertainty. But the scale, dimension, and possible dangerous outcomes, of the problems we face have changed; what was once local and contained can now have international consequences. There is an increasing sense of our vulnerability as the existing systems undergo their cycles of growth, turbulence, transformation, and renewal. The Chinese word for crisis, consists of two characters: one means 'danger' and the other 'opportunity'. Crises in our troubled world should be regarded as creative challenges.

\section{C.S. Holling, Director \\ International Institute for Applied Systems Analysis A-2361 Laxenburg \\ Austria.}

\footnotetext{
* See the account by the then Director of IIASA, Dr Roger E. Levien, entitled 'Ecological Management from an International Perspective', published in Environmental Conservation, 3(3), pp. 183-4, 1976.-Ed.
}

\section{Survival at the Water's Edge?}

In those transitional zones where land and water meet and merge, there lives a community of flora and fauna that is of outstanding importance and yet is at special risk. The Council of Europe's latest campaign sets out to stimulate action to preserve and maintain these areasreturning them, wherever possible, to their natural state. Achievement of this aim should not only guarantee the survival of the plants and animals themselves, but also ensure that resources which are vitally needed by Man continue to be available in future.

Action is needed to reverse the damage that was done when massed resources of mechanical technology were used to shape new shores and river banks and to pen rivers and streams within new and rigid confines. In the process, rivers were straightened and riparian forest, banks green with reeds and other semi-aquatics, freshwater flats and salt-marshes, were lost. Thus, in many parts of Europe, vital spawning, hatching, and feeding, grounds for fish and birds, have disappeared with alarming rapidity.

Industry sprang up along the new banks that had been created with the help of dams and dikes, and oil-tanks, cooling towers, and chimneys, became regular features of the scene. Now a steadily increasingly quantity of waste is carried downstream to the sea. The riverside plant-life, which once helped to repair the damage, has disappeared. For years, too, the leisure boom has been taking millions of people on weekend trips or an annual pilgrimage to rivers, lakes, and the sea. Mass-hotels and camping sites have taken over much of the free space that was left. At the same time, the discharge of waste has combined with oil pollution to make bathing in rivers and off beaches ever more dubious.

We must remember that the built-up shores and river banks of today were for centuries - and particularly when hunting and collecting were major human activitiesareas of vital importance to Man himself. In the shallows, he gathered shell-fish and set his fish-traps. From the stones that littered the shore, he probably manufactured some of his first weapons. Among the reeds, he found birds' nests filled with eggs and lay in wait for the larger animals when they came down to drink.

Today we still feel an atavistic urge to linger on the seashore, searching through the flotsam and driftwood and unconsciously responding to that sense of closeness to the sources of life which Man has always felt in the 
presence of the sea. Water has always been an 'unpredictable element', and early Man took care 'not to settle too close to it, preferring to retreat to the higher ground, or at least to near-by dunes. Eventually, he built houses on stilts in the water, used rubble to construct artificial mounds in the sea, and learned how to tame the waters with the help of dams and new embankments. In time he even learned how these dams and dikes could be used to hold back the sea itself, providing new and fertile land for farming and protecting himself from floods.

Until recently, Europe's river-banks and coastal landscapes were shaped mainly by two flood phenomenarivers in spate and flood-tides at sea. From source to estuary, river-banks were constantly altered by the silt and floating debris carried down from the mountains and hills, while the coastline itself was repeatedly reshaped by ocean-currents and tides. Animals and plants took advantage of these changes, becoming adapted to meet them. Man, on the other hand, took them as a challenge and, after many reverses, succeeded in defeating themonly to end as often the ultimate loser.

The fuller extent of Man's losses became evident as the rivers lost their power to resist pollution, water supplies were endangered, extensive tracts of agricultural and grazing lands became parched, and the recreational potential of the few remaining untouched areas was threatened. These warning signs did not go unheeded. Agreements were reached on the discharge of waste into rivers and on ways of preventing oil-pollution; proposals were made to restrict industrial concentration, and supraregional schemes were devised to control building development along rivers and on coasts. On the Rhine, for example, proposals were made for reopening sections of the river which had previously been closed off, linking them up to form a new river system. Indeed, the variety and range of the problems in different regions is only equalled by the variety and range of the proposals and programmes put forward to solve them!

One thing missing so far, however, has been energetic implementation of those schemes for the improvement and future protection of river-banks and coastlines. This is where the new Council of Europe campaign comes in. It calls on politicians, specialists, and conservation groups, to take action to protect these particularly endangered and vulnerable parts of our natural environment-and also on every individual to ensure, by his personal conduct, that no further damage is done.

What exactly is at stake? The coastal cliffs of Europe, for example, house the continent's largest bird colonies and must be protected against intrusion and oil-spillage. Similarly, the broad mud-flats and the estuaries of nearly all the rivers of Europe are of international importance as nurseries for vital species of fish and as resting places for millions of migratory birds. The main aim here must be to ensure that the long-projected conservation programmes are actually implemented. Along coasts and rivers, comprehensive protection has still to be provided for such waterside areas as have not so far been overrun by the recreation industry. Nearly all of the few remaining tracts of riverside forest are in danger-as are the plants and animals which they shelter and nourish. Whenever it is technically possible, new banks - with appropriate native grasses, forbs, and trees-should be laid out between dikes, dams, and the open water. Boat-owners and surfers must take care not to harm these new plantations, and anglers, hunters, and hikers, can all help to preserve the resting, feeding, and breeding, areas of the wildlife which thrives on river-bank and sea-shore.

Long ago, when the sailors, merchants, and colonists, of old set sail for new shores, this meant a new beginning. Today, our remaining shores and river-banks are no longer new, but old and vulnerable. Nonetheless, we can all make a new beginning by helping to save these places before it is too late.

HENRY MAKOWSKI
c/o Directorate of Press and Information
Council of Europe Secretariat General
BP 431 R6
67006 Strasbourg Cedex
France.

HENRY MAKowski Council of Europe Secretariat General 67006 Strasbourg Cedex France.

\section{What of The Sea Tomorrow?}

The whole range of marine sciences came under review at a European Oceanography Colloquy held in Strasbourg, France, from 19 to 22 June 1983 . The hundred or so specialists at the Colloquy endorsed a plan to set up a European Association of Marine Science and Technology Laboratories, under the auspices of the Council of Europe Parliamentary Assembly.

International cooperation in scientific research and the training of specialists is a precondition of understanding the sea and its resources, and of discovering how to make use of them without upsetting the balance of Nature. Various fields of enquiry were suggested for Europe: deep-water research techniques, the North Atlantic, the South Seas and the Antarctic, the coastal fringe, and exploitation and protection of Mediterranean resources. Noteworthy practical suggestions included the United
Kingdom's proposal to set up a research centre at the University of Stirling, Scotland, to study fish diseases.

Some provisions of the United Nations Convention on the Law of the Sea are so ambiguous, it was noted, that they 'might lead to an outright ban on scientific research', and to avoid this danger participants also proposed that the Council of Europe examine the possibility of drawing up a European regional convention, supplementary to the UN Convention, to remove obstacles to freedom of scientific marine research.

European INFORMATION CENTRE FOR NATURE
CONSERVATION
BP 431 R6
67006 Strasbourg Cedex
France.

European Information CENTRE for NATURE $B P 431 R 6$ France.

\section{Birds that Abandoned Christmas Island Now Returning}

Some six months after they abandoned Christmas Island, the birds were beginning to return to that midPacific atoll, according to Dr Ralph W. Schreiber, the ornithologist who discovered in the autumn of 1982 that almost the entire bird population of the Island about 17 millions-had disappeared. 